\title{
PERAN AKUNTAN MANAJEMEN DALAM MANAJEMEN LINGKUNGAN DAN KINERJA LINGKUNGAN
}

\author{
Oleh Dr.Leny Nofianti MS, SE. M.Si, Ak
}

\begin{abstract}
ABSTRAKSI
Kinerja lingkungan sangat dipengaruhi oleh adanya faktor eksternal seperti kebijakan pemerintah dan tekanan media yang mendorong bagi pengelolaan lingkungan, serta faktor internal seperti kemauan manajemen untuk melakukan manajemen lingkungan secara proaktif. Lebih jauh, manajemen perusahaan juga akan terdorong untuk melakukan pengungkapan environmental disclosure dalam annual report sebagai bagian dari tanggungjawab sosial perusahaan. Persoalan pengungkapan environmental disclosure dalam media publik seperti annual report merupakan hal penting bagi perusahaan ditinjau dari perspektif strategi dan tanggungjawab sosial terhadap publik.

Peran ramah lingkungan dapat dilakukan oleh akuntan manajemen dalam berbagai organisasi dan berbagai posisi jabatannya dalam organisasi tersebut. Tiga diantara banyak peran yang dapat dilakukan terkait dengan peningkatan kualitas informasi lingkungan dan sosial perusahaan. Pertama, mengembangkan kebijakan yang terkait dengan masalah sustainability. Selanjutnya menerapkan, memantau dan mengelola resiko yang terkait dengan pelaksanaan kebijakan tersebut. Kedua, mengidentifikasi secara sukarela aspek lingkungan dan sosial yang sesuai dengan sistem informasi manajemen yang ada. Ketiga, mempertahankan dan memperluas pengetahuan dari peraturan perundang-undangan, pajak dan subsidi yang dapat diterapkan dunia usaha termasuk ketentuan yang terkait dengan kewajiban penyediaan informasi lingkungan dan sosial perusahaan yang relevan.

Kata Kunci: Akuntan manajemen, Manajemen lingkungan, Kinerja lingkungan
\end{abstract}

\section{PENDAHULUAN}

Pemanasan global menjadi pembahasan banyak negara pada akhir-akhir ini. Salah satu sumber penyebabnya tidak lain adanya eksploitasi tak bertanggung jawab yang dilakukan manusia. Atmosfir bumi yang berfungsi sebagai penyaring panas sinar matahari menjadi berlubang sebagai akibat dari "efek rumah kaca". Produk-produk industri tak ramah lingkungan menghasilkan zat-zat yang mengakibatkan berlubangnya lapisan ozon yang ada di atmosfir bumi. Akibat lebih lanjut terjadinya berbagai anomali perubahan iklim. Bahkan disinyalir, akan tenggelamnya sebagian permukaan daratan di muka bumi karena mencairnya es di kutub.

Di Indonesia, permasalahan lingkungan merupakan faktor penting yang harus segera dipikirkan mengingat dampak dari buruknya pengelolaan lingkungan semakin nyata dewasa ini. Gejala ini dapat dilihat dari berbagai bencana yang terjadi akhir-akhir ini, seperti banjir bandang di beberapa daerah di Jawa Tengah dan Jawa Timur, tanah longsor di Desa Sijeruk Jawa Tengah dan daerahdaerah lainnya di Jawa dan Sumatera, serta kebakaran hutan di Riau dan beberapa hutan lindung Kalimantan. Bahkan munculnya banjir lumpur bercampur gas sulfur akhirakhir ini di daerah Sidoarjo Jawa Timur merupakan bukti rendahnya perhatian perusahaan terhadap dampak lingkungan dari aktifitas industrinya. Fakta ini merupakan implikasi, baik langsung maupun tidak langsung, dari rendahnya dorongan dan tindakan proaktif manajemen lingkungan dari berbagai sektor industri di Indonesia.

Permasalahan lingkungan juga semakin menjadi perhatian yang serius, baik oleh 
konsumen, investor maupun pemerintah. Investor asing memiliki kecenderungan mempersoalkan masalah pengadaan bahan baku dan proses produksi yang terhindar dari munculnya permasalahan lingkungan, seperti: kerusakan tanah, rusaknya ekosistem, polusi air, polusi udara dan polusi suara. Senada dengan para investor, pemerintah mulai memikirkan kebijakan ekonomi makro-nya terkait dengan pengelolaan lingkungan dan konservasi alam.

Disadari atau tidak, dampak faham ekonomi kapitalis telah banyak menjalar pada dunia industri modern dewasa ini. Banyak perusahaan yang menerapkan konsep maksimasi laba (salah satu dari konsep yang dianut kaum kapitalis) namun bersamaan dengan itu mereka telah melanggar konsensus dan prinsip-prinsip maksimasi laba itu sendiri. Prinsip-prinsip yang dilanggar tersebut antara lain adalah kaidah biaya ekonomi (economic cost), biaya akuntansi (accounting cost) dan biaya kesempatan (opportunity cost). Implikasi dari pelanggaran terhadap prinsip-prinsip tersebut diantaranya adalah terbengkalainya pengelolaan (manajemen) lingkungan dan rendahnya tingkat kinerja lingkungan serta rendahnya minat perusahaan terhadap konservasi lingkungan. Pelanggaran terhadap opportunity cost misalnya, telah memberi dampak yang signifikan bagi keberlanjutan (sustainability) lingkungan global.

Kepedulian kepada lingkungan sebenarnya juga muncul akibat berbagai dorongan dari pihak luar perusahaan (Berry dan Rondinelli, 1998), antara lain: pemerintah, konsumen, stakeholder dan persaingan. Untuk menindaklanjuti berbagai dorongan ini, maka perlu diciptakan pendekatan secara proaktif dalam meminimalkan dampak lingkungan yang terjadi. Hasil akhir tindakan proaktif manajemen lingkungan tersebut adalah terciptanya kinerja lingkungan perusahaan yang lebih baik.
Penelitian Pfleiger et al (2005) menunjukkan bahwa usaha-usaha pelestarian lingkungan oleh perusahaan akan mendatangkan sejumlah keuntungan, diantaranya adalah ketertarikan pemegang saham dan stakeholder terhadap keuntungan perusahaan akibat pengelolaan lingkungan yang bertanggungjawab dimata masyarakat. Hasil lain mengindikasikan bahwa pengelolaan lingkungan yang baik dapat menghindari klaim masyarakat dan pemerintah serta meningkatkan kualitas produk yang pada akhirnya akan dapat meningkatkan keuntungan ekonomi.

Lebih lanjut, Ferreira menyatakan bahwa persoalan konservasi lingkungan merupakan tugas setiap individu, pemerintah dan perusahaan. Sebagai bagian dari tatanan sosial, perusahaan seharusnya melaporkan pengelolaan lingkungan perusahannya dalam annual report. Hal ini karena terkait dengan tiga aspek persoalan pentingan: keberlanjutan aspek ekonomi, lingkungan dan kinerja sosial. Persoalannya memang pelaporan lingkungan dalam annual report, di sebagian besar negara termasuk Indonesia, masih bersifat voluntary. Di Indonesia sendiri, kewajiban pelaporan dampak lingkungan yang ditetapkan oleh kementrian lingkungan hidup RI hanyalah merupakan pengungkapan yang bersifat nonpublik (khusus terhadap insitusi pemerintah yang terkait).

Berry dan Rondinelli (1998) dan Pfleiger et al (2005) menyatakan bahwa kinerja lingkungan sangat dipengaruhi oleh sejauh mana dorongan terhadap pengelolaan lingkungan dilakukan oleh berbagai instansi khusunya instansi pemerintah. Kinerja lingkungan juga akan tercapai pada level yang tinggi jika perusahaan secara proaktif melakukan berbagai tindakan manajemen lingkungan secara terkendali.

Tulisan ini ingin membahas lebih lanjut bagaimana pentingnya manajemen lingkungan dalam meningkatkan kinerja 
lingkungan dan bagaimana peran akuntan manajemen dalam peningkatan informasi lingkungan dan sosial perusahaan

\section{PEMBAHASAN}

\subsection{Akuntansi Lingkungan}

Akuntansi lingkungan mempunyai beberapa pengertian, menurut Tony Djogo (2006) akuntansi lingkungan adalah istilah yang berkaitan dengan dimasukkannya biaya lingkungan (enviromental cost) ke dalam praktek akuntansi perusahaan atau lembaga pemerintah. Biaya lingkungan adalah dampak baik moneter atau non moneter yang harus dipikul sebagai akibat dari kegiatan yang mempengaruhi kualitas lingkungan. Jadi akuntansi lingkungan hidup adalah metodologi untuk menilai biaya dan manfaat dari sebuah kegiatan lingkungan untuk mengurangi dampak lingkungan.

Hasil akuntansi ini digunakan oleh para pimpinan perusahaan untuk membuat keputusan yang berkaitan dengan perbaikan lingkungan. Tujuan dari penerapan akuntansi lingkungan adalah sebagai berikut:

a. Akuntansi lingkungan merupakan sebuah alat manajemen lingkungan. Sebagai alat manajemen lingkungan akuntansi lingkungan digunakan untuk menilai keefektifan kegiatan konservasi berdasarkan ringkasan dan klasifikasi biaya konservasi lingkungan. Data akuntansi lingkungan juga digunakan untuk menentukan biaya fasilitas pengelolaan lingkungan, konservasi lingkungan keseluruhan dan juga investasi yang diperlukan untuk kegiatan pengelolaan lingkungan. Selain itu akuntansi lingkungan juga digunakan untuk menilai tingkat keluaran dan capaian tiap tahun untuk menjamin perbaikan kinerja lingkungan yang berlangsung terus menerus.

b. Akuntansi lingkungan sebagai alat komunikasi dengan masyarakat. Sebagai alat komunikasi publik, akuntansi $\begin{array}{lrr}\text { lingkungan } & \text { digunakan } & \text { untuk } \\ \text { menyampaikan } & \text { dampak } & \text { negatif }\end{array}$ lingkungan, kegiatan konservasi lingkungan dan hasilnya kepada publik. Tanggapan dan pandangan terhadap akuntansi lingungan dari berbagai pihak, pelanggan dan masyarakat digunakan sebagai umpan balik untuk merubah pendekatan perusahaan dalam pelestarian dan pengelolaan lingkungan.

Dalam himpunan istilah lingkungan untuk manajemen (Handri Santiago) dalam Sherlina (2006), pengertian akuntansi lingkungan dikemukakan secara rinci bahwa akuntansi lingkungan merupakan proses akunting yang:

1. Mengenali, mencari dan kemudian mengurangi efek-efek lingkungan dari pelaksanaan praktek laporan yang konvensional.

2. Mengenali secara terpisah biaya-biaya dan penghasilan yang berhubungan dengan lingkungan dalam sistem laporan yang konvensional

3. Mengambil langkah-langkah aktif untuk menyusun inisiati-inisiatif untuk memperbaiki efek-efek lingkungan yang timbul dari praktek-praktek pelaporan konvensional

4. Merencanakan bentuk-bentuk baru sistem laporan-laporan finansial dan non finansial, sistem informasi dan sistem pengawasan untuk lebih mendukung keputusan manajemen yang secara lingkungan tidak berbahaya

5. Mengembangkan bentuk-bentuk baru dalam pengukuran kinerja, pelaporan dan penilaian untuk tujuan internal dan eksternal

6. Mengenali, mencari, menguji dan memperbaiki area-area dimana kriteria finansial konvensional dan kriteria lingkungan bertentangan

7. Mencoba cara-cara dimana sistem berkelanjutan dapat dinilai dan 
digabungkan menjadi kebiasaan yang berhubungan dengan organisasi

Beberapa aspek yang menjadi bidang akuntansi lingkungan hidup antara lain (Halim,1999; 20):

1. Pengakuan dan identifikasi pengaruh negatif aktivitas binis perusahaan terhadap lingkungan dalam praktek akuntansi konvensional.

2. Identifikasi, mencari dan memeriksa persoalan bidang akuntansi konvensional yang bertentangan dengan kriteria lingkungan hidup serta memberikan alternatif solusinya.

3. Beberapa bidang akuntansi konvensional dan keuangan yang bertentangan dengan kriteria dan pemikiran lingkungan hidup antara lain:

a. Kriteria penilaian investasi dan kinerja perusahaan. Analisa investasi seringkali tidak mempertimbangkan sepenuhnya biaya-biaya dan keuntungan-keuntungan yang digabung dengan aktivitas lingkungan.

b. Penganggaran terbatas. Alokasi dana yang dibuat belum mempertimbangkan masalah lingkungan

c. Kinerja harga saham. Harga saham tidak menunjukkan gambaran yang sesungguhnya dari kegiatan operasional perusahaan

\section{d. Pelaporan devein}

e. Peramalan bisnis

f. Prioritas laporan keuangan tahunan

g. Pembuatan sistem informasi baru

h. Penilaian biaya design dan biaya lingkungan hidup (eksternalitas)
4. Melaksanakan langkah-langkah proaktif dalam menyusun inisiatif untuk memperbaiki dampak lingkungan hidup pada praktek akuntansi konvensional

5. Pengembangan format baru akuntansi keuangan dan non keuangan

6. Sistem informasi dan sistem pengendalian pendukung kepentingan manajemen ramah lingkungan

7. Identifikasi biaya-biaya manfaat berupa pendapatan apabila perusahaan lebih peduli terhadap lingkungan hidup dan berbagai program perbaikan

8. Pengembangan format kerja

9. Penilaian dan pelaporan internal dan eksternal perusahaan

Dalam beberapa literatur, akuntansi lingkungan disebut juga akuntansi biaya lingkungan. Akuntansi biaya lingkungan menurut Junus dalam Sherlina (2006) adalah identifikasi, pengukuran dan alokasi biayabiaya lingkungan hidup dan penginterasian biaya-biaya ini kedalam pengambilan keputusan usaha serta pengkomunikasian hasilnya kepada stakeholder perusahaan.

Praktek-praktek akuntansi tradisional seringkali melihat biaya lingkungan sebagai biaya mengoperasikan bisnis, meskipun biaya-biaya tersebut signifikan, meliputi : biaya berdaya, yaitu mereka yang secara langsung berhubungan dengan produksi dan mereka yang terlibat dalam operasi bisnis umum, pengolahan limbah, dan biaya pembuangan. Biaya reputasi lingkungan, dan biaya membayar premi asuransi resiko lingkungan.

Dalam banyak kasus, biaya-biaya lingkungan seperti yang berkaitan dengan sumberdaya alam (energi, udara, air) dimasukkan ke dalam satu jalur 'biaya operasi' atau 'biaya administrasi' yang diperlakukan independen dengan proses 
produksi. Juga biaya lingkungan sering didefinisikan secara sempit sebagai biaya yang terjadi dalam upaya pemenuhan dengan atau kaitan dengan hukum atau peraturan lingkungan. Hal ini karena sistem akunting cenderung berfokus pada biaya bisnis yang teridentifikasi secara jelas, bukan pada biaya dan manfaat pilihan alternatif. Akuntansi Lingkungan secara spesifik mendefinisikan dan menggabungkan semua biaya lingkungan ke dalam laporan keuangan perusahaan. Bila biaya-biaya tersebut secara jelas teridentifikasi, perusahaan akan cenderung mengambil keuntungan dari peluang-peluang untuk mengurangi dampak lingkungan. Manfaat -manfaat dari mengadopsi akuntansi lingkungan dapat meliputi :

1. Perkiraan yang lebih baik dari biaya sebenarnya pada perusahaan untuk memproduksi produk atau jasa. Ini bermuara memperbaiki harga dan profitabilitas

2. Mengidentifikasi biaya-biaya sebenarnya dari produk, proses, sistem, atau fasilitas dan menjabarkan biaya-biaya tersebut pada tanggungjawab manajer

3. Membantu manajer untuk menargetkan area operasi bagi pengurangan biaya dan perbaikan dalam ukuran lingkungan dan kualitas

4. Membantu dengan penanganan keefektifan biaya lingkungan atau ukuran perbaikan kualitas

5. Memotivasi staf untuk mencari cara yang kreatif untuk mengurangi biaya biaya lingkungan.

6. Mendorong perubahan dalam proses untuk mengurangi penggunaan sumberdaya dan mengurangi, mendaur ulang, atau mengidentifikasi pasar bagi limbah

7. Meningkatkan kepedulian staf terhadap isu -isu lingkungan, kesehatan dan keselamatan kerja
8. Meningkatkan penerimaan konsumen pada produk atau jasa perusahaan dan sekaligus meningkatkan daya kompetitif.

\section{Biaya lingkungan}

Biaya lingkungan adalah dampak, baik moneter atau non -moneter terjadi oleh hasil aktifitas perusahaan yang berpengaruh pada kualitas lingkungan. Bagaimana perusahaan menjelaskan biaya lingkungan tergantung pada bagaimana perusahaan menggunakan informasi biaya tersebut (alokasi biaya, penganggaran modal, disain proses/produk, keputusan manajemen lain), dan skala atau cakupan aplikasinya. Tidak selalu jelas apakah biaya itu masuk lingkungan atau tidak, beberapa masuk zona abu -abu atau mungkin diklasifikasikan sebagian lingkungan sebagian lagi tidak. Terminologi akuntansi lingkungan menggunakan ungkapan seperti full, total, true, dan life cycle untuk menegaskan bahwa pendekatan tradisional adalah tidak lengkap cakupannya karena mereka mengabaikan biaya lingkungan penting (serta pendapatan dan penghematan biaya).

Sistem akuntansi konvensional biasanya mengklasifikasi biaya sebagai :

a. Biaya langsung material dan buruh

b. Biaya pabrik manufaktur atau factory overhead atau termasuk biaya tak langsung (biaya operasi selain biaya langsung buruh dan material, seperti depresiasi modal, sewa, pajak bangunan, asuransi, pasokan, utilitas, pemeliharaan dan perbaikan, dan biaya operasi pabrik)

c. Penjualan

d. Biaya umum dan administratif (General \& Administrative)

e. Biaya riset dan pengembangan (R\&D)

Panduan GEMI dan EPA menjelaskan klasifikasi biaya lingkungan :

1. Biaya konvensional --> biaya penggunaan material, utilitas, benda modal, dan pasokan. 
2. Biaya berpotensi tersembunyi -->

a. Biaya 'upfront' : yang terjadi karena operasi proses, sistem, atau fasilitas

b. Biaya 'backend' : biaya prospektif, yang akan terjadi tidak tentu dimasa depan.

c. Biaya pemenuhan peraturan atau setelah pemenuhan (voluntary, beyond compliance), yaitu biaya yang terjadi dalam operasi proses, sistem, fasilitas, umumnya dianggap biaya overhead

3. Biaya tergantung (contingent) --> biaya yang mungkin terjadi di masa depan dijelaskan dalam bentuk probabilistik

4. Biaya imej dan hubungan (image and relationship) --> seperti biaya pelaporan dan aktifitas hubungan masyarakat.

Investasi untuk menjadi entitas ramah lingkungan perlu biaya besar. Hal ini yang sering menjadi pertimbangan bagi perusahaan untuk nekat melaksanakan operasinya tanpa mempedulikan dampak lingkungan yang diakibatkannya. Misalnya perusahaan dengan tanpa memasang peralatan penetral limbah dari produk-produk kimia akan mengeluarkan biaya yang lebih rendah dibandingkan dengan perusahaan yang memasang alat penetral limbah. Harga produk perusahaan tersebut lebih murah dengan kualitas yang sama. Pelanggan akan memilih produk yang harganya murah dan berkualits jika dibanding produk yang sama dengan harga lebih mahal.

Untuk sementara waktu, kondisi seperti ini memang memiliki kesan lebih menguntungkan. Namun, jika ditinjau secara makro sebetulnya kerugian yang besar sudah terjadi. Kerugian masyarakat akibat pencemaran yang terjadi karena produk menghasilkan limbah yang mencemarkan lingkungan tidak diperhitungkan. Padahal dari usaha perusahaan yang tidak ramah lingkungan masyarakat menanggung kerugian yang lebih besar dari keuntungan yang diraup oleh perusahaan tersebut.
Sehingga, saat ini pandangan masyarakatpun telah berubah. Produk ramah lingkungan sudah mulai banyak dipilih oleh para pelanggan. Keputusan pelanggan untuk membeli produk tidak hanya semata didasarkan hanya pada murahnya harga produk tetapi informasi non-finansial juga menjadi penentu. Produk dengan label ramah lingkungan, misalnya akan dipilih untuk dibeli.

\section{Manajemen Lingkungan dan Kinerja Lingkungan}

Berry dan Rondinelly (1998), mensinyalir ada beberapa kekuatan yang mendorong perusahaan untuk melakukan tindakan manajemen lingkungan. Faktorfaktor tersebut adalah:

1. Regulatory demand, tanggung jawab perusahaan terhadap lingkungan muncul sejak 30 tahun terakhir ini, setelah masyarakat meningkatkan tekanannya kepada pemerintah untuk menetapkan peraturan pemerintah sebagai dampak meluasnya polusi. Sistem pengawasan manajemen lingkungan menjadi dasar untuk skor lingkungan, seperti programprogram kesehatan dan keamanan lingkungan. Perusahaan merasa penting untuk bisa mendapatkan penghargaan di bidang lingkungan, dengan berusaha menerapkan prinsip-prinsip TQEM secara efektif, misalnya dengan penggunaan tehnologi pengontrol polusi melalui penggunaan clean technology. Di sisi lain, berbagai macam regulasi tentang lingkungan belum mampu menciptakan win-win solution diantara pihak terkait dalam menciptakan inovasi dan persaingan serta tingkat produktivitas yang tinggi terhadap seluruh perusahaan. Porter (1995), mengindikasikan bahwa dalam pembuatan regulasi lingkungan hendaknya melibatkan para enviromentalist, legeslatif dan perusahaan, sehingga dapat menciptakan mata rantai ekonomi, yakni 
environment, produktivitas sumber daya, inovasi dan persaingan.

2. Cost factors, adanya komplain terhadap produk-produk perusahaan, akan membawa konsekwensi munculnya biaya pengawasan kualitas yang tinggi, karena semua aktivitas yang terlibat dalam proses produksi perlu dipersiapkan dengan baik. Hal ini secara langsung akan berdampak pada munculnya biaya yang cukup tinggi, seperti biaya sorting bahan baku, biaya pengawasan proses produksi, dan biaya pengetesan. Konseksensi perusahaan untuk mengurangi polusi juga berdampak pada munculnya berbagai biaya, seperti penyediaan pengolahan limbah, penggunaan mesin yang clean technology, dan biaya pencegahan kebersihan.

3. Stakeholder forces. Strategi pendekatan proaktif terhadap manajemen lingkungan dibangun berdasarkan prinsip-prinsip manajemen, yakni mengurangi waste dan mengurangi biaya produksi, demikian juga respond terhadap permintaan konsumen dan stakeholder. Perusahaan akan selalu berusaha untuk memuaskan kepentingan stakeholder yang bervariasi dengan menemukan berbagai kebutuhan akan manajemen lingkungan yang proaktif.

4. Competitive requirements, semakin berkembangnya pasar global dan munculnya berbagai kesepakatan perdagangan sangat berpengaruh pada munculnya gerakan standarisasi manajemen kualitas lingkungan. Persaingan nasional maupun internasional telah menuntut perusahaan untuk dapat mendapatkan jaminan dibidang kualitas, antara lain seri ISO 9000. Sedangkan untuk seri ISO 14000 dominan untuk standar internasional dalam sistem manajemen lingkungan. Keduanya memiliki perbedaan dalam kriteria dan kebutuhannya, namun dalam pelaksanaannya saling terkait, yakni dengan mengintegrasikan antara sistem manajemen lingkungan dan sistem manajemen perusahaan. Untuk mencapai keunggulan dalam persaingan, dapat dilakukan dengan menerapkan green alliances (Hartman dan Stafford, 1995). Green alliances merupakan partner diantara pelaku bisnis dan kelompok lingkungan untuk mengintegrasikan antara tanggungjawal lingkungan perusahaan dengan tujuan pasar.

$\begin{array}{lcr}\text { Berbagai } & \text { dorongan di } & \text { atas } \\ \text { mengkondisikan perusahaan } & \text { untuk } \\ \text { melakukan manajemen lingkungan } & \text { secara }\end{array}$ melakukan manajemen lingkungan secara proaktif. Sistem manajemen proaktif merupakan sistem manajemen lingkungan yang komprehensif yang terdiri dari kombinasi lima (5)pendekatan, yaitu: (1) meminimalkan dan mencegah waste, (2) manajemen demand side, (3) desain lingkungan (4) product stewardship dan (5) akuntansi full-costing.

Meminimalkan dan mencegah waste, merupakan perlindungan lingkungan efektif yang sangat membutuhkan aktivitas pencegahan terhadap aktivitas yang tidak berguna. Pencegahan polusi merupakan penggunaan material atau bahan baku, proses produksi atau praktek-praktek yang dapat mengurangi, miminimalkan atau mengeliminasi penyebab polusi atau sumbersumber polusi. Tehnologi yang terkait dengan pencegahan polusi dalam bidang manufaktur meliputi: pengganti bahan baku, modifikasi proses, penggunaan kembali material, recycling material dalam proses selanjutnya, dan penggunaan kembali material dalam proses yang berbeda (reuse). Tuntutan aturan dan cost untuk pengawasan polusi yang semakin meningkat merupakan faktor penggerak bagi perusahaan untuk menemukan cara-cara yang efektif dalam mencegah polusi.

\begin{tabular}{lllr}
\multicolumn{2}{c}{ Demand-side } & management, \\
merupakan & sebuah & pendekatan dalam \\
pencegahan & polusi yang asal mulanya
\end{tabular}


digunakan dalam dunia industri. Konsep ini difokuskan pada pemahaman kebutuhan dan preferensi konsumen dalam penggunaan produk, dan didasarkan pada tiga prinsip yang mendasar, yaitu: tidak menyisakan produk yang waste, menjual sesuai dengan jumlah kebutuhan konsumen dan membuat konsumen lebih effisien dalam menggunakan produk. Demand-side management industri mengharuskan perusahaan untuk melihat dirinya sendiri dalam cara pandang baru, sehingga dapat menemukan peluang-peluang bisnis baru.

Desain lingkungan, merupakan bagian integral dari proses pencegahan polusi dalam manajemen lingkungan proaktif. Perusahaan sering dihadapkan pada ineffisiensi dalam mendesain produk, misalnya produk tidak dapat dirakit kembali, di-upgrade kembali, dan di-recycle. Design for environmental (DFE) dimaksudkan untuk mengurangi biaya reprocessing dan mengembalikan produk ke pasar secara lebih cepat dan ekonomis.

Produk stewardship merupakan praktek-praktek yang dilakukan untuk mengurangi resiko terhadap lingkungan melalui masalah-masalah dalam desain, manufaktur, distribusi, pemakaian atau penjualan produk. Di beberapa negara telah muncul peraturan bahwa perusahaan bertanggung jawab untuk melakukan reclaim, recycling dan re-manufacturing produk mereka. Dengan menggunakan life-cycleassesment (LCA) dapat ditentukan cara-cara perusahaan dalam mengurangi atau mengelimasi waste dalam seluruh tahapan, mulai dari bahan mentah, produksi, distribusi dan penggunaan oleh konsumen (Dias et al, 2004). Alternatif produk yang memiliki less pollution dan alternatif material, sumber energi, metode prosessing yang mengurangi waste menjadi kebutuhan bagi perusahaan.

Full cost environmental accounting, merupakan konsep cost environmental yang secara langsung akan berpengaruh terhadap individu, masyarakat dan lingkungan yang biasanya tidak mendapatkan perhatian dari perusahaan. Full cost accounting berusaha mengidentifikasi dan mengkuantifikasi kinerja biaya lingkungan sebuah produk, proses produksi dan sebuah proyek dengan mempertimbangkan empat macam biaya, yaitu : (1) biaya langsung, seperti biaya tenaga kerja, biaya modal dan biaya bahan mentah. (2) biaya tidak langsung, seperti biaya monitoring dan reporting. (3) biaya tidak menentu, misalnya biaya perbaikan. (4) biaya yang tidak kelihatan, seperti biaya publik relation dan good will.

Sebagai ukuran keberhasilan perusahaan dalam melaksanakan menejemen lingkungan proaktif, maka dapat dilakukan dengan mengidentifikasi kinerja lingkungan proaktif. Penerapan manajemen lingkungan proaktif memerlukan keterlibatan beberapa prinsip dasar kedalam strategi perusahaan. Prinsip-prinsip tersebut antara lain :

a. Mengadopsi kebijakan lingkungan yang bertujuan mengeleminasi polusi berdasarkan pada posisi siklus hidup operasional perusahaan, dan mengkomunikasikan kebijakan keseluruh perusahaan dan para stakeholder.

b. Menetapkan secara obyektif kriteria efektivitas program lingkungan.

c. Membandingkan kinerja lingkungan perusahaan dengan perusahaan-perusahaan yang merupakan leader dalam satu industri dengan benchmarking dan menetapkan praktik terbaik (best practice).

d. Menetapkan budaya perusahaan bahwa kinerja lingkungan merupakan tanggung jawab seluruh karyawan.

e. Menganalisis dampak berbagai isue lingkungan dalam kaitannya dengan permintaan dimasa depan terhadap produk dan persaingan industri.

f. Memberanikan diri melakukan diskusi tentang isu-isu lingkungan, khususnya melalui rapat pimpinan. 
g. Mengembangkan anggaran untuk pembiayaan lingkungan.

h. Mengidentifikasi dan mengkuantifikasikan pertanggungjawaban lingkungan.

Meskipun demikian, selama ini pengukuran terhadap kinerja lingkungan masih belum ada kesepakatan final. Hal ini karena setiap negara memiliki cara pengukuran sendiri tergantung situasi dan kondisi lingkungan negara masing-masing. Sebagai contoh, Kementrian Lingkungan Hidup Indonesia telah menerapkan PROPER sebagai alat untuk memeringkat kinerja lingkungan perusahaan-perusahaan yaang ada di Indonesia. Terdapat 42 karakteristik untuk menilai kinerja lingkungan dengan 5 peringkat: (1) Gold dengan 42 karakteristik, (2) Green dengan 37 karaketriskan penilaian, (3) Blue dengan 19 karakteristik, (4) Red dengan 5 karakteristik, serta (4) Black dengan karakteristik kurang dari 5. Sistem penilaian yang diatur berdasar sistem gugur.

Wiseman (1982) menggunakan 4 dimensi untuk mengukur sistem peringkat kinerja lingkungan, masing-masing adalah dimensi ekonomi, pertauran hukum, pengurangan polusi, dan informasi lingkungan yang terkait. Berbagai konsep pengukuran lainnya telah dikembangkan oleh Robert (1991), SustainaAbility (1997) dan Kurt dan Munis (1998). Review yang telah dilakukan oleh Jones dan T. Alabaster (1999) menunjukkan bahwa dari sekian konsep yang ada, hanya konsep Krut dan Munis (1998) yang dipandang memenuhi standar pengukuran dalam pespektif axiomatis dari skala ordinal.

Berbagai penelitian terdahulu telah dilakukan untuk menunjukkan bahwa kinerja lingkungan berhubungan dengan faktorfaktor non keuangan serta faktor-faktor keuangan seperti kinerja keuangan, harga saham, dan biaya modal. Namun hasil-hasil penelitian tersebut justru menunjukkan bahwa faktor non keuangan merupakan explanatory varibles penting bagi environmental disclosure.. Penelitian Pattern (1991, 1992) menunjukkan bahwa ukuran perusahaan (size) dan industry merupakan faktor-faktor yang mempengaruhi environmental disclosure, namun profitability bukan merupakan explanatory variables bagi environmental disclosure. Hogner (1982) membuktikan bahwa social disclosure merupakan respon dari dorongan dan perilaku sosial.

Brown dan Deegan (1998) menguji hubungan antara tekanan media cetak terhadap tingkat environmental disclosure dalam annual report. Hasilnya menunjukkan adanya hubungan yang signifikan. Neu, et al, (1998) membuktikan bahwa voluntary environmental disclosure berhubungan negatif dengan profitabilitas, tetapi berhubungan positif dengan tekanan dan lingkungan media terhadap faktor lingkungan serta kuantitas dari voluntary environmental disclosure lainnya. Di Indonesia, penelitian yang menghubungkan antara faktor nonkeuangan, seperti ukuran dan profil dewan komisaris, terhadap corporate social responsibilty disclosure dilakukan oleh Sembiring (2005). Hasilnya menunjukkan adanya hubungan signifikan antara kedua variabel. Dalam penelitian yang sama, Sembiring (2005) juga menguji hubungan antara variabel profitabilitas dan leverage dengan corporate social disclosure, namun hasilnya tidak menunjukkan hubungan yang signifikan.

Menurut Berry dan Rondinelli (1998) dan Pfleiger et al (2005), kinerja lingkungan sangat dipengaruhi oleh adanya faktor eksternal seperti kebijakan pemerintah dan tekanan media yang mendorong bagi pengelolaan lingkungan, serta faktor internal seperti kemauan manajemen untuk melakukan manajemen lingkungan secara proaktif. Lebih jauh, manajemen perusahaan juga akan terdorong untuk melakukan pengungkapan environmental disclosure 
dalam annual report sebagai bagian dari tanggungjawab sosial perusahaan. Persoalan pengungkapan environmental disclosure dalam media publik seperti annual report merupakan hal penting bagi perusahaan ditinjau dari perspektif strategi dan tanggungjawab sosial terhadap publik. Environmental disclosure itu sendiri merupakan perilaku yang berbasis pada le gitimacy theory (Cormier, et al, 2004).

\section{Pengungkapan Kinerja Pengelolaan Lingkungan Perusahaan}

Berdasarkan UU No. 23 tahun 1997 mengenai Pengelolaan Lingkungan Hidup beserta peraturan pelaksanaannya, kinerja pengelolaan lingkungan wajib diungkapkan dan disampaikan oleh setiap orang/penanggung-jawab kegiatan. Kecuali AMDAL dan pengendalian pencemaran udara, seluruh informasi kinerja pengelolaan lingkungan tersebut hanya disampaikan kepada instansi lingkungan hidup. Masyarakat yang ingin mengetahuinya harus mencari akses sendiri. Pada era keterbukaan dengan makin didorongnya penerapan corporate governance pada perusahaan serta peran serta yang lebih besar pada masyarakat untuk menilai kinerja pengelolaan lingkungan, keterbatasan akses untuk menyampaikan dan mencari informasi tersebut menjadi kendala.

Beberapa perusahaan skala besar, terutama yang sudah tercatat di pasar modal serta mempunyai dampak yang besar dan penting terhadap lingkungan, secara sukarela mengungkapkan kinerja pengelolaan lingkungannya dalam berbagai spektrum, baik melalui pelaporan yang terpisah maupun menjadi bagian dari Laporan Tahunan. Akan tetapi, jumlah perusahaan yang sudah melakukan pengungkapan informasi pengelolaan lingkungan ini sangat terbatas. Laporan kinerja pengelolaan lingkungan yang disampaikan perusahaan kepada instansi lingkungan saat ini hanya berupa laporan penaatan (Compliance Report) dengan format dan istilah yang sulit dimengerti oleh orang awam maupun oleh pihak yang berprofesi non lingkungan. Oleh karena itu, adanya penyampaian informasi kinerja ketaatan pengelolaan lingkungan secara informatif kepada publik sangat diperlukan, sekaligus untuk mengukur efektifitas penerapan CSR pada perusahaan.

\section{Peran Akuntan Manajemen dalam peningkatan kualitas informasi lingkungan dan sosial perusahaan}

Penyempurnaan kandungan informasi dalam laporan keuangan yang ada saat ini dapat dilakukan antara lain melalui pengaturan dalam akuntansi manajemen dan akuntansi keuangan. Akuntansi manajemen dapat memulainya dengan meningkatkan perannya. Professional Accountants in Business (PAIB) Committe IFAC, Agustus 2006 menerbitkan tulisan yang berjudul "Why Sustainability Counts for Professional Accountants in Business". Tulisan tersebut mendorong agar akuntan manajemen profesional dapat mengambil peran untuk memberikan pemahaman, melakukan tindakan dan mencapai efesiensi entitas melalui praktik usaha yang ramah lingkungan.

Peran tersebut dapat dilakukan oleh akuntan manajemen dalam berbagai organisasi dan berbagai posisi jabatannya dalam organisasi tersebut. Tiga diantara banyak peran yang dapat dilakukan terkait dengan peningkatan kualitas informasi lingkungan dan sosial perusahaan. Pertama, mengembangkan kebijakan yang terkait dengan masalah sustainability. Selanjutnya menerapkan, memantau dan mengelola resiko yang terkait dengan pelaksanaan kebijakan tersebut. Kedua, mengidentifikasi secara sukarela aspek lingkungan dan sosial yang sesuai dengan sistem informasi manajemen yang ada. Ketiga, mempertahankan dan memperluas pengetahuan dari peraturan 
perundang-undangan, pajak dan subsidi yang dapat diterapkan dunia usaha termasuk ketentuan yang terkait dengan kewajiban penyediaan informasi lingkungan dan sosial perusahaan yang relevan.

Selain itu International Federation Of Accountants (IFAC) juga telah menerbitkan Guidebook for Environmental Management Accounting (EMA). Akuntansi manajemen lingkungan merupakan pengelolaan kinerja lingkungan dan ekonomi melalui pengembangan dan penerapan praktik dan sistem akuntansi terkait lingkungan yang tepat. Selain itu, United Nations Expert Working Group on EMA mendefenisikan "akuntansi manajemen lingkungan" adalah seluruh kegiatan dalam rangka mengidentifikasi, mengumpulkan, menganalisis dan mengunakan dua informasi utama untuk pengambilan keputusan internal. Informasi pertama mengenai informasi fisik atas penggunaan, aliran dan tujuan akhir dari energi, air dan bahan baku (termasuk limbah). Sedangkan informasi kedua mengenai informasi moneter atas lingkungan, terkait dengan biaya, laba dan penghematan.

Akuntansi manjemen lingkungan mengembangkan mengembangkan biayabaiaya yang harus ditanggung perusahaan sebagai upaya untuk mengendalikan dan mencegah limbah dan polusi yang dapat merusak lingkungan dan kesehatan manusia. Misalnya biaya-biaya yang terjadi untuk mencegah dihasilkannya limbah atau polusi; biaya pengendalian dan daur ulang limbah yang dihasilkan; dan biaya untuk memulihkan wilayah yang terkena polusi. Jenis biaya-biaya ini sering disebut sebagai environmental protection expenditures (EPEs). Meskipun demikian biaya-biaya terkait dengan EMA bukanlah hanya EPE, tetapi termasuk di dalamnya seluruh biaya yang secara efektif dikeluarkan untuk mengelola kinerja lingkungan.

Akuntansi bahan fisik (Phisical Material Accounting) ditujukan untuk menyediakan informasi fisik penggunaan bahan dan produk fisik yang dihasilkan. Pasokan bahan baku adalah energi, air atau bahan baku lainnya ke dalam entitas. Keluarannya adalah produk, limbah atau bahan lainnya yang ditinggalkan entitas. Ada keluaran yang bukan produk keluaran yang diistilahkan sebagai non produk keluaran. Entitas yang mengunakan energi dan bahan baku tetapi entitas tersebut bukan industri manufaktur yang menghasilkan produk fisik, seperti transortasi dan sektor jasa lainnya, semua energi, air dan bahan baku lainnya yang digunaka, seringkali, akan meninggalkan non produk keluaran, seperti terlihat pada tabel 1 di bawah ini.

Tabel 1. Informasi fisik atas penggunaan bahan dan produk keluaran

\begin{tabular}{|c|c|c|}
\hline $\begin{array}{c}\text { Bahan } \\
\text { Masukan }\end{array}$ & Produk Keluaran & $\begin{array}{c}\text { Non-Produk } \\
\text { Keluaran }\end{array}$ \\
\hline $\begin{array}{l}\text { - Bahan baku } \\
\text { dan } \\
\text { pendukung }\end{array}$ & \begin{tabular}{|l} 
- $\begin{array}{l}\text { Produk utama } \\
\text { (termasuk } \\
\text { kemasan) }\end{array}$ \\
\end{tabular} & $\begin{array}{l}\text { - Limbah } \\
\text { padat }\end{array}$ \\
\hline $\begin{array}{l}\text { - Bahan } \\
\text { Kemasan }\end{array}$ & $\begin{array}{l}\text { - } \begin{array}{l}\text { Produk } \\
\text { sampingan } \\
\text { (termasuk } \\
\text { kemasan) }\end{array} \\
\end{array}$ & $\begin{array}{l}\text { - Limbah } \\
\text { berbahaya }\end{array}$ \\
\hline - Bahan Jadi & & $\begin{array}{l}\text { - Limbah } \\
\text { cair }\end{array}$ \\
\hline $\begin{array}{l}\text { - Bahan } \\
\text { Operasi }\end{array}$ & & - Polusi \\
\hline - Air & & \\
\hline - Energi & & \\
\hline
\end{tabular}

Sumber: Sri Yanto, Majalah Akuntan Indonesia, 2007

Akuntansi moneter (monetary accounting) ditujukan untukmemberikan informasi dampak moneter atas penggunaan bahan dan produk keluaran yang dihasilkan dalam proses produksi atau pemberian jasa yang dilakukan entitas. Biaya-biaya yang terjadi dapat diklasifikasikan menjadi enam jenis biaya.

Pertama, biaya bahan dari produk keluaran. Biaya-biaya tersebut termasuk biaya perolehan dari sumber daya alam 
seperti air dan bahan baku lain yang diubah menjadi produk, produk sampingan dan kemasan. Kedua, biaya bahan dari non produk keluaran. Biaya-biaya tersebut termasuk biaya perolehan (dan kadangkala biaya pemrosesan) energi, air dan bahan lain untuk menjadi non produk keluaran (limbah dan polusi).

Ketiga, biaya pengendalian limbah dan polusi. Biaya-biaya tersebut termasuk untuk penanganan, pendauran dan pembuangan limbah dan polusi; biaya pemulihan dan kompensasi terkait kerusakan lingkungan; dan biaya dalam rangka analisis dampak lingkungan. Keempat, biaya pencegahan dan pengelolaan lingkungan lainnya. Biaya-biaya tersebut termasuk biaya kegiatan pengelolaan pencegahan lingkungan seperti perencanaan dan sistem lingkungan, pengukuran lingkungan, komunikasi lingkungan dan kegiatan lain yang relevan.

Kelima, biaya riset dan pengembangan. Biaya-biaya tersebut termasuk biaya-biaya riset dan pengembangan terkait proyek lingkungan. Keenam, less tangible cost. Biaya termasuk biaya-biaya, baik internal maupun eksternal, terkait isu less tangible. Misalnya termasuk kewajiban, regulasi di masa depan, produktivitas, citra perusahaan, hubungan dengan para stakeholder dan eksternalitas.

\section{Penutup}

Saat ini pandangan masyarakatpun telah berubah. Produk ramah lingkungan sudah mulai banyak dipilih oleh para pelanggan. Keputusan pelanggan untuk membeli produk tidak hanya semata didasarkan hanya pada murahnya harga produk tetapi informasi non-finansial juga menjadi penentu. Produk dengan label ramah lingkungan, misalnya akan dipilih untuk dibeli.

Kinerja lingkungan sangat dipengaruhi oleh adanya faktor eksternal seperti kebijakan pemerintah dan tekanan media yang mendorong bagi pengelolaan lingkungan, serta faktor internal seperti kemauan manajemen untuk melakukan manajemen lingkungan secara proaktif. Lebih jauh, manajemen perusahaan juga akan terdorong untuk melakukan pengungkapan environmental disclosure dalam annual report sebagai bagian dari tanggungjawab sosial perusahaan. Persoalan pengungkapan environmental disclosure dalam media publik seperti annual report merupakan hal penting bagi perusahaan ditinjau dari perspektif strategi dan tanggungjawab sosial terhadap publik.

Peran ramah lingkungan dapat dilakukan oleh akuntan manajemen dalam berbagai organisasi dan berbagai posisi jabatannya dalam organisasi tersebut. Tiga diantara banyak peran yang dapat dilakukan terkait dengan peningkatan kualitas informasi lingkungan dan sosial perusahaan. Pertama, mengembangkan kebijakan yang terkait dengan masalah sustainability. Selanjutnya menerapkan, memantau dan mengelola resiko yang terkait dengan pelaksanaan kebijakan tersebut. Kedua, mengidentifikasi secara sukarela aspek lingkungan dan sosial yang sesuai dengan sistem informasi manajemen yang ada. Ketiga, mempertahankan dan memperluas pengetahuan dari peraturan perundang-undangan, pajak dan subsidi yang dapat diterapkan dunia usaha termasuk ketentuan yang terkait dengan kewajiban penyediaan informasi lingkungan dan sosial perusahaan yang relevan.

\section{DAFTAR PUSTAKA}

Berry A Michael dan Dennis A Rondinelli. 1998. Proactive Corporate Environmental Management: A New Industrial Revolution. Academy of Management Executive. 12(2). 38-50.

Brown N. and C. Deegan.1998. The Public Disclosure of environmental performance information- dual test of media agenda setting theory and 
legitimacy theory. Journal Accounting and Business Reaserch. 29(1). 21-41.

Cormier, D. Irene M Gordon, Michael Magnan. 2004. Corporate Environmental Disclosure; Contrasting Managements perception with reality. Journal of Business Ethices. 49. 143.

Dias, Ana Claudia; Margarida Louro; Luis Arroja; Isabel Capela . 2004. Evaluation of the environmental performance of printing and writing paper using life cycle assessment. Management of Environmental. Vol. 15 , No.5

Djogo Tony, 2006, Akuntansi Lingkungan (Environmental Accounting), www.beritabumi.com , diakses 29 April 2009

Ferreira, Clementina. 2004. Environmental accounting: the Portuguese case, Management of Environmental. Vol. 15, No. 6.

Halim, Abdul, 1999, Perspektif Teori Akuntansi Keuangan terhadap Masalah Lingkungan, Jurnal Ekonomi dan Bisnis Indonesia, Volume 14 Nomor 2: 101-112.

Hartman L Cathy dan Stafford R Edwin. 1997. Green Alliances: Building New Business with Environmental Group. Long Range Planning. Vol. 30, no.2, pp. 184-196.

Jones dan T. Alabaster (1999), Critical Analysis of corporate environmental reporting scoring system. Journal of Environmental Assessment Policy and Management 1(1). 27-60.

Krut, R. \& Munis, K. 1998. Sustainable industrial development: Benchmarking environmental policies and reports. Greener Management International. 21. 87-98

Neu, D.H. Warsam dan K. Pedwell. 1998. Managing Public Impression:
Environemntal disclosure in annual report. Accounting Organization and Society. 23(3). 265-286

Patten, D.M.1991. Exposure legitimacy, and social disclosure. Journal of Accounting and Public Policy. 10. 297308.

Patten, D.M. 1992. Intra Industry Environmental Disclosures in response to the Alaskan oil spill: a note on legitimacy theory. Accounting, Organization and Society. 17(5). 471475.

Pflieger, Juli; Matthias Fischer; Thilo Kupfer; Peter Eyerer. 2005. The contribution of life cycle assessment to global sustainability reporting of Organization. Management of Environmental. Vol. 16, No. 2.

Sembiring, Eddy Rismanda, Karakteristik Perusahaan dan pengungkapan tanggung jawab sosial: study empiris pada perusahaan yang tercatat di Bursa Efek Jakarta. Seminar Nasional Akuntansi VII. Solo. 379-395.

Sherlina, 2006, Pengaruh ukuran Perusahaan dan Financial Performance Terhadap Pengungkapan Informasi Lingkungan Hidup (Environmental Disclosure) Pada Laporan Tahunan Perusahaan, Universitas Brawijaya, Malang

SustainAbility/UNEP (1997) Engaging Stakeholders: The 1997 Benchmark Survey

Sri Yanto, 2007, Akuntansi Hijau: Sarana Pendeteksi Dini Bencana Lingkungan, Majalah Akuntan Indonesia

Wiseman, J. 1982. An evaluation of environmental disclosures made in corporate annual reports. Accounting, Organization and Society. 7(1). 53-63. 